\title{
SEED GERMINATION ECOLOGY AND SEEDLING EMERGENCE OF SIXTEEN TREE SPECIES AUTUMN SOWN
}

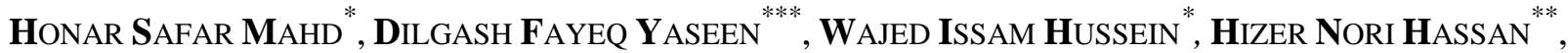 \\ Mohammed T. Selah-Alden ${ }^{* *}$, MOHAMmed J. MAHMOOd ${ }^{* *}$, NARIN Ali HAMEed ${ }^{* *}$, GaIlan B. \\ AHMED $^{* * *}$ and SAMI MoHAMEd AMIN Ali YousseF ${ }^{*}{ }^{* * * *}$ \\ *Dept.of Recreation and Ecotourism,College of Agriculture,University of Duhok, Kurdistan Region-Iraq. \\ ** Malta nursery, Duhok, Kurdistan Region-Iraq. \\ **** Dept. of Forestry, College of Agriculture, University of Duhok, Kurdistan Region-Iraq. \\ **** University of Montpellier-France.
}

(Received:August 6, 2017; Accepted for publication: November 13, 2017)

\begin{abstract}
In nature, the regeneration and the seed germination ecology of tree species is varied due to divers' environmental factors and evolution process. As a consequence, understanding the factors controlling the seed germination and seedling emergence in the time and the space. In most nurseries, tree seeds are usually sown in spring or rarely in autumn and, they are often pretreated to increase the seed germination where the germination timing is selective sieve that a plant experiences throughout its life history. However, in most nursery of Kurdistan region, the managers have not a good knowledge about the seeds sowing timing and seedling emergency of native tree species. Therefore, the main aim of this study is to investigate seed germination phenology with providing new data and determine optimal ways of seed sowing time that will permit a best seedling establishment of sixteen native and introduced tree species. The results showed, the seed sowing timing and seedling emergence of these tree species. In addition, these species exhibit significant divergence in term sowing timing and seedling establishment. Thereby, our results have a high value for managers of Kurdistan governmental and private nurseries as a suggestion which exact time is better for sowing seeds and which seeds need pre-treatment before sowing in order to obtain better regeneration.
\end{abstract}

KEYWORDS: Sowing timing, Seedling emergency, Germination timing, Regeneration,

\section{INTRODUCTION}

I the life cycle of a plant species, germination processes is a more crucial phase which greatly affecting its population dynamic, regeneration and fitness as well as its persistence (Fenner \&Thompson 2005). Germination as part of plant's life history strategy, it is an irreversible biological process:Once germination has started the embryo is committed irrevocably to growth or death (Baskin \& Baskin 2014). Generally, in order for the seeds of a species to germinate, they must be in suitable environmental conditions "germination niche" which usually favour the growth and establishment of the seedlings (Harper 1977). Consequently, a good understanding of the ecological factors controlling the germination in time and space is crucial for optimal biodiversity conservation and future management (Galme's et al. 2006; Mattana et al. 2010; Abdoallahi et al. 2012). Furthermore, in case of endangered species, a major priority in efforts to conserve these species is to maintain their evolutionary potential and thus their persistence by understanding and improving their germination (Fenner \& Thompson 2005; Lecket al. 2008).To achieve this aim, information must be obtained concerning the seed germination ecology and seedling recruitment in the life cycle of target species (Baskin and Baskin 2000; Leck et al. 2008, Imbert et al. 2012).

In literature, a range of seed ecology attributes such as seed production, seed mass, germination percentage, seed longevity seed viability, seedling growth and the presence of a soil seed bank have well be studied in both the laboratory and the Field (see e.g. Baskin \& Baskin 2014; Fenner\& 
Thompson 2005; Youssef et al. 2011). However, our understanding of both seed sowing timing and seedling emergence timing remain incomplete and in need of additional scientific investigations (McMillan-Browse, 1978; McDonald, 1986; Dirr and Heuser, 1987; Young and Young, 1992, Takos \& Efthimiou 2003; Donohue 2005). In most nurseries around the world, tree seeds are usually sown in spring or rarely in autumn followed by the weather conditions and/or control conditions "green house" that increase significantly the seed germination (Takos \& Efthimiou 2003). In this circumstance, managers often use pre-treatments in order to breakdown physical and/or physiological seed dormancy by e.g. mechanical scarification, cold stratification, chemical scarification (Baskin \& Baskin 2014). In term of seed dormancy, management practice and germination required temperature. Forest tree seeds can be sown in three different seasons (autumn, springs and summer) seeds sown. Mild and cold winter predominate the management practice (Hartmann et al, 1997).

Germination timing is selective sieve "evolution process" where the season of germination determined by the seasonal environment that a plant experiences throughout its life history i.e. autumn, winter, spring summer germination phenology (Topham et al, 2017).

Seeds of tree species whose viability decreases rapidly should be sown immediately (e.g, Ulmus). While, the large seeds are often prefered outdoors autumn season sowing such as Castanea spp., Aesculus spp., Quercus spp., Corylus spp., if these seeds are not stored properly in winter the quality of seeds reduce after harvesting (Dirr and Heuser, 1987; Takos and Merou, 1995; Hartmann et al., 1997; Takos et al., 2002). Seeds that have dormancy in embryo, autumn sowing is usually used for these seeds e.g, Taxus spp, Malus spp., Prunus spp., Pyrus spp. (Hartmann et al., 1997), because low temperature of winter cannot break the embryo dormancy of seeds. As well as autumn sowing is using for the species that have embryo dormancy with hard coat for example Crataegus spp. Berberis spp., Cotinus spp., Cornus spp.(Lawyer, 1978), some other seeds whose sown early (Dirr and Heuser, 1987). However, the disadvantages of autumn seeds sowing. High temperature of autumn lead seeds to germinate which insecure the seeds to low temperature in winter which may damage seed embryo (Hartmann et al, 1997). In addition, the late spring frost may damage the seed due to premature germination in spring. Seeds with wings and large seeds may endanger by Rodents (Hartmann et al, 1997).

The aim of this study is to investigate both seeds sowing timing and seedling emergency timing germination of some Kurdistan region forest tree species. Without pre-treatment and after fall sowing and to permit spring sowing some seed may require some pre-treatment to remove dormancy. Therefore, the present study focus on two essential objectives in particular: (i) Provide new data in terms of seed germination phenology and thus identify the major differences in seed germination timing that might contribute tomanagement practices for local nurseries (ii) Determine optimal ways of seed sowing time that will permit a best seedling establishment. The species which were studied have not been examined after sowing under the weather conditions of autumn in Duhok province, Kurdistan region of Iraq. This study will help to show governmental and private nurseries the exact time for some tree seeds to be seeded and what type of seeds need pre-treatment before sowing as well as some other agricultural sectors that deal with seeds dormancy.

\subsection{Site Study:}

\section{MATERIAL AND METHODS}

Field experiment was carried out on 01 October 2016 in Malta nursery, Duhok province, Kurdistan region of Iraq (42 56’05.68 E, 36 51 '27.96' N) (Fig. 1) which located between Mediterranean and Irano-Anatolian region (Youssef et al, 2015). It is the main forest nursery which provides directory of agriculture and directory of forest and rangelands with tree seedlings as well as providing Duhok city with seedling for urban forestry and Green belts. It is a governmental nursery established to supply all public and private sectors with tree seedlings in order to increase the urban green areas which in turn will play a remarkable role in temperature diminishing, protecting soil from erosion and water run-off cases, increase the aesthetic value and quality of places, promote recreation and reduce pollution (see Nowak et al. 2013; Tasoulas et al, 2013).

According to bioclimatic data from Malta nursery - Duhok, the city is belongs to the Mesopotamian region and having some Mediterranean climate features (Youssef et al. 
2015). As well as according to the classification of Köppen-Geiger climate system (Peel et al. 2007) it classified as a semi-arid region. Weather conditions (Rainfall, temperature) as well as starting precipitation season and ending season in the nursery were the mean annual temperature for 2016 - 2017 was $26.7^{\circ} \mathbf{C}$, the average annual precipitation in Malta nursery was (386mm), while the precipitation started on 28 October 2016 and ended on May 20 of 2017.

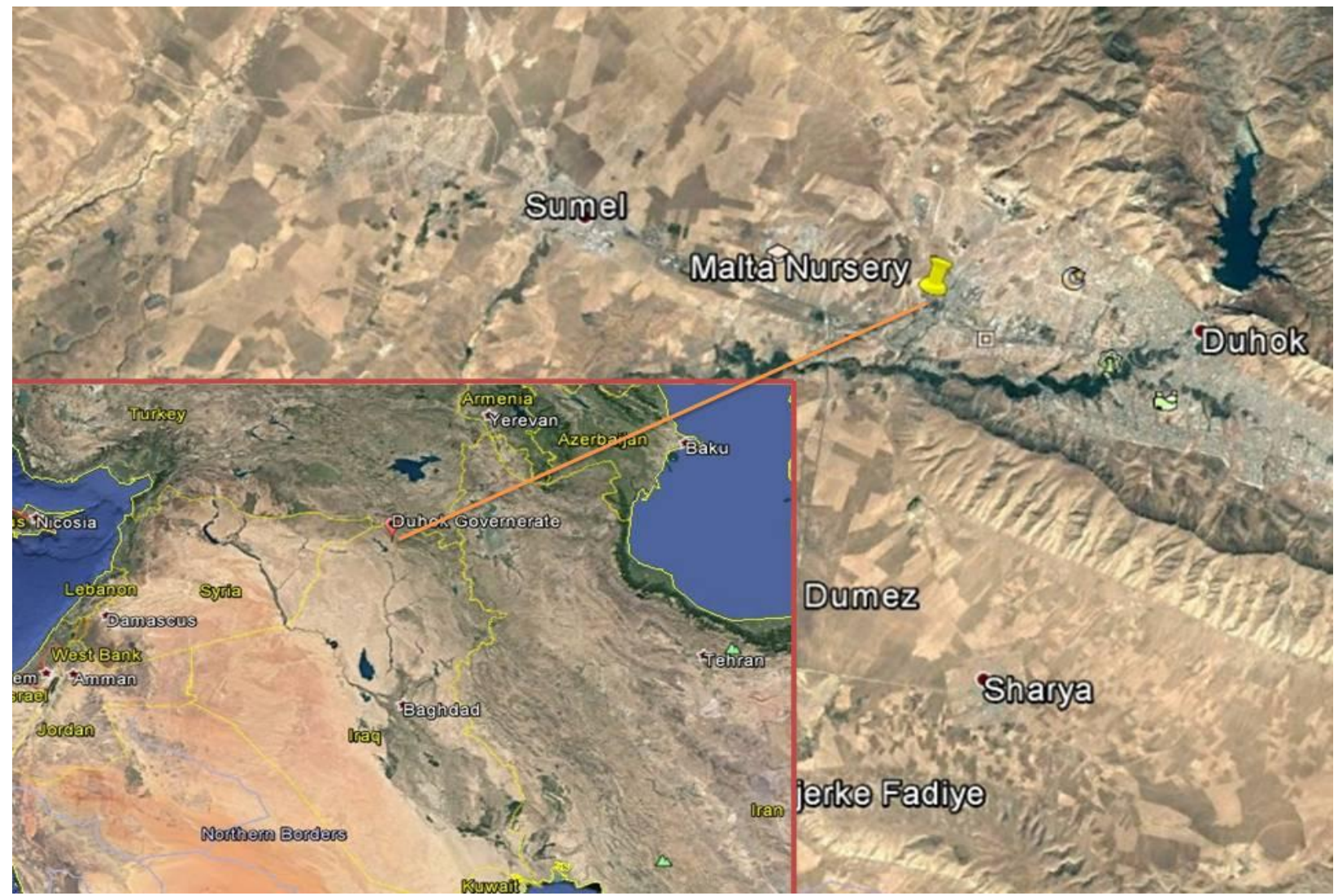

Fig. (1): Location of Malta Nursery in Duhok Governorate - Kurdistan region

\subsection{Tree species study:}

In this study, sixteen tree species were used in field experiment (see Table 1) for more details about the species, collected date and location and storage condition). These trees species are more used in nursery of Kurdistan Region in general and in Malta nursery in particular. First, fully matured seeds of each tree species were collected from plants with a vigorous and healthy appearance growing in field. Seed collection was carried out on summer 2015; and seed collected was cleaned, and then dried progressively up for 20-30 days at room temperature, and then preserved in air tight vase at before germination studies were initiated.

A 100 -seed lot issued from each tree species were selected and then they distributed into four
25 -seed replicates. They were seeded in black pots (1 liter) containing sandy soil in normal blocks each pot with sand and 25 seed per pot. (Krussmann, 1981) study method was used for the depth of planted seeds, which highlighted that the planted seed in the soil equal three times of seed size. After dispersing the seeds in the black pots a thick layer of sand were covered the seeds about 2 $-3 \mathrm{~mm}$, this cover will resist seed to rain, hail and sun in the winter (Krussmann, 1981). Irrigation was started at the beginning of March until germination completion. Seedling measurements were taken place weekly at the beginning of seed germination until completion of emergence which was from December until June of 2016. 
Table (1) :Tree species, abbreviation, collection date and location of mother plant, seed storage conditions until seed sowing.

\begin{tabular}{|c|c|c|c|c|c|}
\hline Number & Tree species & abbreviation & Collection date & $\begin{array}{l}\text { Location of Mother } \\
\text { Plant }\end{array}$ & $\begin{array}{ll}\text { Seed } & \text { storage } \\
\text { conditions } & \\
\end{array}$ \\
\hline 1 & Melia azedarach & Melazd & 2015 & Malta Nursery, Duhok & $\begin{array}{l}\text { Air tight vase at room } \\
\text { temperature }\end{array}$ \\
\hline 2 & Parkinsonia aculeata & Paracu & 2015 & Hawler city & $\begin{array}{l}\text { Air tight vase at room } \\
\text { temperature }\end{array}$ \\
\hline 3 & Ceratonia siliqua & Cersil & 2015 & Mazi Garden, Duhok & $\begin{array}{l}\text { Air tight vase at room } \\
\text { temperature }\end{array}$ \\
\hline 4 & Pistacia eurycarpa & Piseur & 2015 & Mountain, & $\begin{array}{l}\text { Air tight vase at room } \\
\text { temperature }\end{array}$ \\
\hline 5 & Pyrus syriaca & Pyrsyr & 2015 & $\begin{array}{l}\text { Mateen Mountain, } \\
\text { Deralok }\end{array}$ & $\begin{array}{l}\text { Air tight vase at room } \\
\text { temperature }\end{array}$ \\
\hline 6 & Pistacia khinjuk & Piskhi & 2015 & $\begin{array}{l}\text { Mateen Mountain, } \\
\text { Deralok }\end{array}$ & $\begin{array}{l}\text { Air tight vase at room } \\
\text { temperature }\end{array}$ \\
\hline 7 & Celtis australis & Celaus & 2015 & Gara Mountain & $\begin{array}{l}\text { Air tight vase at room } \\
\text { temperature }\end{array}$ \\
\hline 8 & Lauru s nobilis & Launob & 2015 & Mazi garden, Duhok & $\begin{array}{l}\text { Air tight vase at room } \\
\text { temperature }\end{array}$ \\
\hline 9 & Paliurus spina-christi & Palspi & 2015 & Zawita District, Duhok & $\begin{array}{l}\text { Air tight vase at room } \\
\text { temperature }\end{array}$ \\
\hline 10 & Pinus brutia & Pinbru & 2015 & Malta nursery, Duhok & $\begin{array}{l}\text { Air tight vase at room } \\
\text { temperature }\end{array}$ \\
\hline 11 & Robinia pseudoacacia & Robpse & 2015 & Malta nursery, Duhok & $\begin{array}{l}\text { Air tight vase at room } \\
\text { temperature }\end{array}$ \\
\hline 12 & Sorbus umbellata & Sorumb & 2015 & $\begin{array}{l}\text { Gara Mountain, } \\
\text { Duhok }\end{array}$ & $\begin{array}{l}\text { Air tight vase at room } \\
\text { temperature }\end{array}$ \\
\hline 13 & Cercis siliquastrum & Cersis & 2015 & Malta nursery, Duhok & $\begin{array}{l}\text { Air tight vase at room } \\
\text { temperature }\end{array}$ \\
\hline 14 & Rhus coriaria & Rhucor & 2015 & Mateen Mountain & $\begin{array}{l}\text { Air tight vase at room } \\
\text { temperature }\end{array}$ \\
\hline 15 & Juniperus oxycedrus & Junoxy & 2015 & Malta nursery, Duhok & $\begin{array}{l}\text { Air tight vase at room } \\
\text { temperature }\end{array}$ \\
\hline 16 & Crataegus azarolus & Craaza & 2015 & Mateen Mountain & $\begin{array}{l}\text { Air tight vase at room } \\
\text { temperature }\end{array}$ \\
\hline
\end{tabular}




\section{RESULTS AND DISCUSSION}

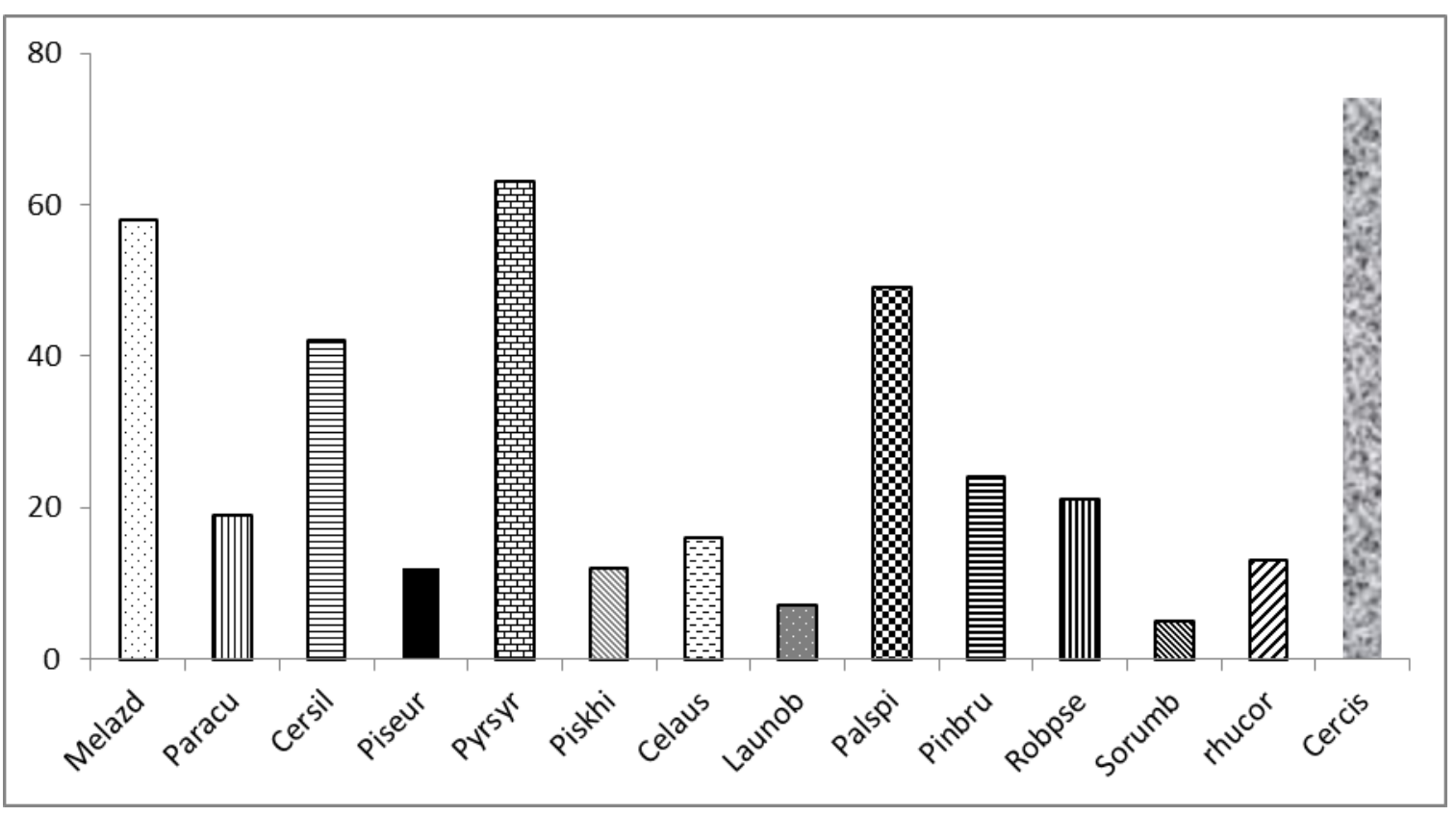

Fig. (2) : Forest tree species and seed germination rate

\subsection{Seed Germination of Tree species Melia azedarach}

The seed germination percentage of the species Melia azedarach (Figure 2) was about 58\%. This shows that the germination rate of species is good and it does not need for pre-treatment as the study result of (Salim Azad, et al, 2010) of Melia azedarach seed germination was $53.3 \%$. Parkinsonia aculeata

The study result shows (Figure 2) that germination rate of Parkinsonia aculeate was approximately $19 \%$. This rate of germination is not good but as well as it is not a slight rate comparing to the result of (Vora, 1989) study which was $8 \%$ seed germination, this may because the environmental conditions were more suitable that the area where the study of (Vora, 1989).

Ceratonia siliqua

Seed germination of Ceratoniasiliqua was $42 \%$ (Figure 2). The rate of germination was good comparing to the study of (Gunes, et al, 2013) similar findings was gained from this study which was $(13.57 \%)$ out of 27 seeds.

Pistacia eurycarpa
Findings shows germination rate of Pistacia eurocarpa was $12 \%$ (Figure 2). The result of germination may be it is slight but comparing to a kilogram of seed is good without pre-treatment. While, the study of (Mahdi et al, 2016 Inedit) showed that the perfect pre-treatment is 10 minutes soaking in $\mathrm{H} 2 \mathrm{SO} 4$ and the result was $42 \%$ out of 100 seeds. As well as, paper of (Ellis et al, 1985) recommended the same pre-treatment.

Pyrus syriaca

In regard to germination rate of Pyrus syriaca was $(68 \%)$ (Figure 2). The rate of germination was very good in compare with the result of the study of (Al-Bukhari, 2002) which was $40 \%$, this may be because Pyrus syriacais native to Kurdistan region of Iraq and it is more adapted to the environmental condition in the native area.

Pistacia khinjuk

Findings shows germination rate of Pistacia khinjuk was $12 \%$ (Figure 2). The result of germination may be it is slight but comparing to a kilogram of seed is good without pre-treatment. While (Mahdi et al,2016 Inedit) showed that the perfect pre-treatment is 10 minutes soaking in $\mathrm{H} 2 \mathrm{SO} 4$ and the result was $35 \%$ out of 100 seeds. 
As well as, paper of (Ellis et al., 1985) recommended the same pre-treatment.

Celtis australis

The findings showed that seed germination of this species was (16\%) (Figure 2).This finding is good but for better results need pre-treatment which supported by some other studies (Ellis et al., 1985; Hartmannet al., 1997, Takos and Efthimiou. 2003).

\section{Laurus nobilis}

The findings showed that seed germination of this species was (16\%) (Figure 2).This finding is good but for better results need pre-treatment which supported by some other studies (Young and Young, 1992; Takos and Merou, 1995; Hartmann et al, 1997). (Takos, 2001) reported that cold season may destroy the seeds (Laurus nobilis). Hence, cold season sowing must be avoided Paliurus spina-christi

Seed germination of Paliurus spina-christi was (49\%) (Figure 2).This shows that the germination rate of species is good and it does not need for pre-treatment and the research results disagreed with the result of the study of (Pipinis, Milios, and Smiris, 2011) conducted in Greece,where it is noticed that the germination of controlled seeds was low (4.17\%). This might be because the environmental conditions were more suitable in Malta Nursery than the area in Greece.

Pinus brutia

The seed germination percentage of the species Pinus brutia was 24\% (Figure 2). This is one of Kurdistan region native tree and the result showed that seed germination rate of pinus bruita was good which is similar to the findings of the research of (Skordilis and Thanos 1995) whom reported that the seed germination of Pinus brutia was about nearly (20\%) that has been conducted inGreece.

\section{Robinia pseudoacacia}

Seed germination percentage of Robinia pseudoacacia (Figure 2) was (21\%). This showed that rate of germination is not good but however, it is not a slight rate but in comparison with the paper of (Masaka and Yamada 2009) it has approximately the same result $22 \%$ of seed germination.

\section{Sorbus umbellata}

Seed germination percentage of Sorbus umbellate (Figure 2) was (5\%). This showed that rate of germination is not good and it require pretreatment and this was similar to the findings of (Gultekin, et al. 2007) who reported that the weight of 1000 Sorbus umbellata seeds only $23.3 \mathrm{~g}$ were germinated and the best pre-treatment was stratification for 45 to 75 days.

\section{Cercis siliquastrum}

Seed germination percentage of Cercis siliquastrum (Figure 2) was (74\%). The result showed that this species does not need any pretreatment because the rate of germinated seeds was good, comparing to the study of (Takos and EFthimion 2003) which was very poorly germinated $(21 \%)$.

\section{Rhus coriaria}

The result showed that seed germination rate was (13\%) (Figure 2). The outcome that obtained from this research was better than the result of study of (Takos and Efthimion 2003) which was about (0\%); this is due to the double dormancy that the Rhus coriaria has it. It requires pretreatment to break dormancy (Young and Young, 1992).

Juniperus oxycedrus and Crataegus azarolus

There was no germinated seed recorded for these two species Juniperus oxycedrus and Crataegus azarolus (Figure 2). The result of this study showed that this two species require pretreatment because it has two types of dormancy or double dormancy (Takos and Efthimion 2003) physical (hard coat) and physiological (embryo dormancy). The study of (Ma'an development center 2017) highlighted the best pre-treatment for these two species is scarification for 3 months. 


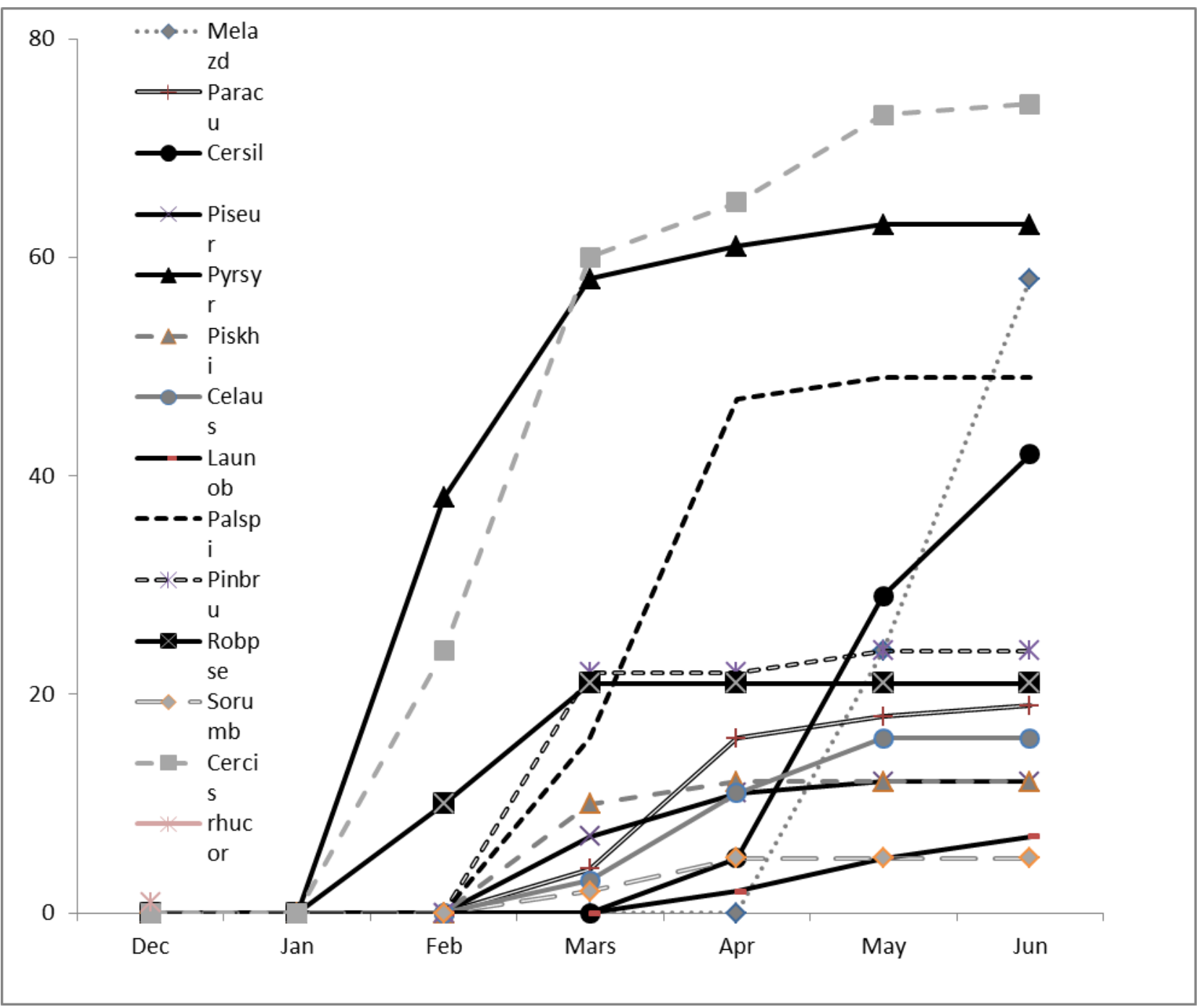

Fig. (3) : Suitable sowing time

\subsection{Suitable sowing timing of tree species}

2.3.

Group1: Late winter seedling emergence (Pyrus syriaca, Robinia pseudoacacia, Cercis siliquastrum)

The best time for seeds sowing of this group of tree species should be on the winter period. Actually, the seeds of the tree species belonging to this group 1 began to germinate on the January (see figure. 3) and it achieve the optimal germination rate on March and April. According to (flora of Iraq) Pyrus syriaca and Cercis siliquastrum both are native to Kurdistan region of Iraq and both adapted to the environmental conditions of the area and got optimal germination before drying season. For better germination sulphuric acid scarification is the best pretreatment (Piotto and Di Noi 2003).
Group 2: Early spring seedling emergence (Pinus brutia, Paliurus spina-christi, Pistacia Khinjuk, Parkinsonia aculeate, Pistacia eurycarpa, Celtis australis, Sorbus umbellata, Rhus coriaria)

The study results showed that this group of tree species sowing time should be on late winter-early spring. Actually, the germination of seeds of these tree species group started from February and it obtained the optimal germination on March to April (see figure. 3). Almost all this group tree species belong to Irano-anatolian and Mediterranean region (Piotto and Di Noi, 2003). So, it needs humidity and wait until the cold season finish until February and rain season continue until April. There is some species require pre-treatment before sowing such us Pistacia spp 10 minutes soaking in $\mathrm{H} 2 \mathrm{SO} 4$ and Sorbusumbellatabest pre-treatment was 
stratification for 45 to 75 days (Gultekin et al. 2007). (Young and Young, 1992) has recommended scarification for Rhus coriaria. Eight days stratification recommended by (Piotto and Di Noi 2003).Pinus spp. best sowing time start on March (figure 2). For Pinus brutia as well as, clay + ash as growing media has the best significant effect on growth of Pinus spp (Salih T., W. 2016).

Group 3: Spring seedling emergence (Ceratonia siliqua, Laurus nobilis)

This group of tree species sowing should initiate on early spring. Actually, the seeds of these tree species germinate in spring (March) and it achieve the optimal germination on May and June (see figure 3). Seed germination of Ceratonia siliqua was good (see figure. 1). It belongs to Fabaceae family and has a hard coat and need one month to be in humidity to break that hard coat. For better germination Mechanical scarification was recommended by (Piotto and Di Noi 2003).

Group 4: Early summer seedling emergence (Melia azedarach)

This tree species sowing time should be in late spring. Its seeds start the germination process from April and it obtained the optimal germination on May to June (see figure. 3). Thus, according to this research the nurseries should initiate sowing species seeds on April, due to high level of humidity and the seeds are large, the study show that seeding in January, February and March may cause rodent to the seeds of Melia spp. (Hartmann etal., 1997) highlighted that the fall sown may cause rodent large seeds. This species is belonging to tropical species and it is not native to Kurdistan region of Iraq, so it needs irrigation at the first step of seeding these seeds on April.

Group 5: Seeds needs pretreatment (Juniperus oxycedrus and Crataegus azarolus)

It cannot recommend any sowing time for this two species because there was no germinated seed recorded for this group of tree species. The result of this study showed that these group of tree species need pre-treatment due to their double "physical-physiological" dormancy. Collecting seeds from the area that have animal strobili (Wild boar, foxes, etc) as well as, 30-90 dayscold stratification of seed nakedly recommended by (Piotto and Di Noi 2003) and (Ortiz P., L. 1998). The best pre-treatment for Crataegus azarolus suggested by (Ma'an development center, 2017) which is seeds fermentation for few days in its pulp.
2.3
Seedling
emergence
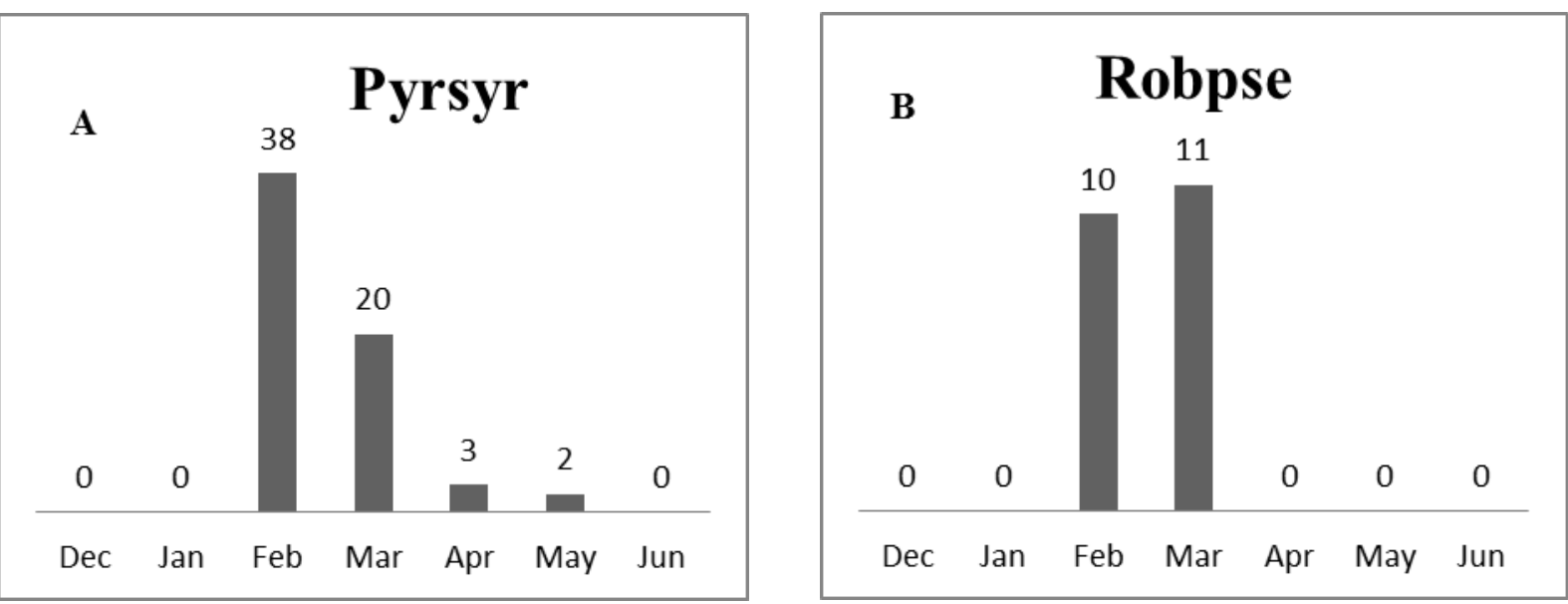

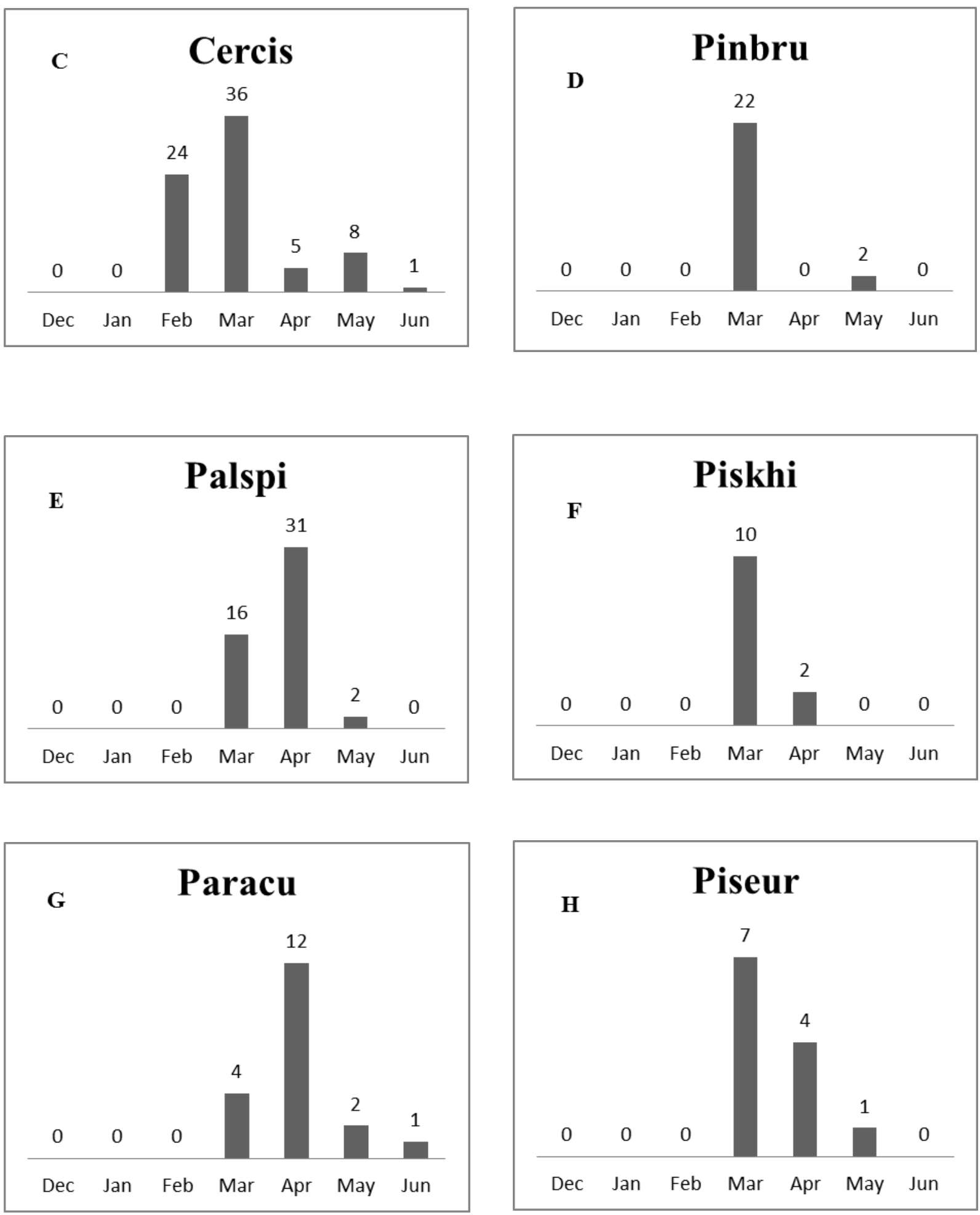

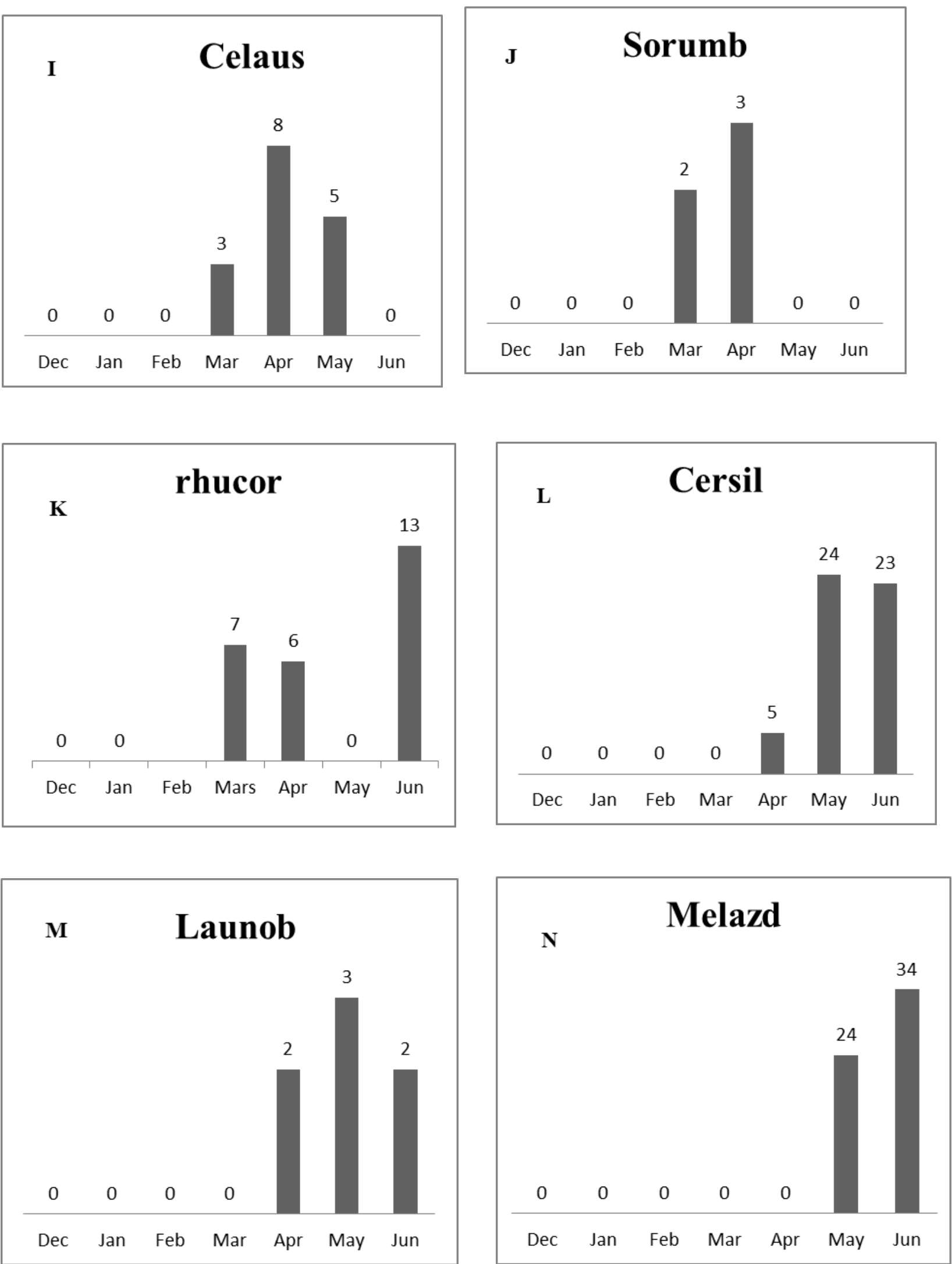

Fig. (4 A to N) : Shows seedlings emergence 
Pyrus syriaca, Robinia pseudoacacia, Cercis siliquastrum

Figure (4 abc); shows seedlings emergence for all three species. Pyrus syriaca start seedling emergence on February (38), March (20), April (3) and May (2), Furthermore, Robinia pseudoacacia started on February (10) and March (11) seedlings. In addition, Cercis siliquastrum started seedlings on February, March, April, May and June $(24,36,5,8,1)$ respectively.

Pinus brutia, Paliurus spina-christi, Pistacia khinjuk, Parkinsonia aculeate, Pistacia eurocarpa, Celtis australis, Sorbus umbellata, Rhus coriaria

The best seedlings emergence were started on March with (22) seedlings and May (20) seedlings March and April were the best seedlings started for both pistacia eurocarpa (7 to 4) seedlings respectively and pistacia khinjuk (10 to 2) seedlings respectively. Celtis australis initiate on March with 3 seedlings followed by (8) in April and (5) seedlings on May. paliurus spina-christi began on March, April to May (16,31 to 2) respectively. Parkinsonia aculeate initiate on March with (4) seedlings (12) seedlings on April, May (2) seedlings and (1) on June. Sorbus umbellata began on March to April (2 seedlings to 3 seedlings) respectively. Similarly for Rhus coriaria which initiate (7) seedlings in March and (6) seedlings on April (see figure 4 defghijk).

Ceratonia siliqua, Laurus nobilis

Figure (4 lm); Shows the best seedlings emergence for both species which start on April to June. Ceratonia silique seedlings start growing on April continued to May and June $(5,24,23)$ seedlings accordingly. Similarly to lauru nobilis growing seedlings start $(2,3$, 2) on April, May and June respectively.

Melia azedarach

As it has been previously showed in (see figure $4 \mathrm{n}$ ) that the optimal seedlings emergence started on may to June (24 to 34) respectively. If it has been seeded early may cause rodent to the seeds of Melia spp. (Hartmann et al., 1997) highlighted that the fall sown may cause rodent large seeds. So, the paper suggestion for nurseries to start sowing seeds on April, because it is native to Tropical rain forest which needs temperature and moisture.

Juniperus oxycedrus and Crataegus azarolus

According to research findings there was no seedlings emergence, because there was no germinated seed recorded for this group of tree species. The result of this study showed that these group of tree species need pre-treatment. 30-90 days cold stratification of seed naked recommended by (Piotto and Di Noi 2003) and (Ortiz P., L. 1998). The best pre-treatment for Crataegus azarolus suggested by (Ma'an development center, 2017) which is seeds fermentation for few days in its pulp.

\section{CONCLUSION AND RECOMMENDATION}

The findings on sixteen native and non native tree species (see table 1) were showed for the first time on all around the Kurdistan region of Iraq and Middle East some tree species have a good germination rate, while some other require pre-treatment to germinate. Moreover, the results showed that each tree species has its own sowing time, because of having a special cells for dormancy and special cells responsible for germination. Thus, this shows for all Nurseries specially Malta Nursery as a suggestion which time is good for sowing seeds in order to obtain better results because early sown may lead to seed rodent and later than showed time in the research may the temperature kill the seeds.

The study suggested that first it's important to conduct a research on the rest of the tree species that is not have been studied in this research. Second, Malta nursery producing seedlings from many non-native tree species for example (Eucalyptus spp, Melia spp, etc). It is better to produce from native tree species seedlings such as (Pistacia spp and Pyrus syriaca), because it has adaptation to the local environment. Furthermore, these native tree species have multiple roles and functions towards improving the urban environment. They can be used for green belts; urban forestry, urban carbon sequestration, air purification and give aesthetic to the area, as well as, the fruits are edible by human and wildlife.

\section{REFERENCES}

- Abdollahi J., Ebrahimi M., Ramshini H.A., JaafariA.A., Eftekhari M., Mansouri Y.S. and Goharrizi M.A.S.B. (2012). Seed germination as the major conservation issue of endemic Iranian salvia species. Journal of Medicinal Plants Research. 6: 37-46.

- Al-Bukhari, F. M., Qrunfleh, M. M., \& Al-Eisawi, D. M. (2002). propagation of Pyrus syriaca by seeds and stem cuttings. Actahorticulturae.

- Baskin J.M. and Baskin C.C. (2000). Seed germination ecology of Lesquerellalyrata Rollins (Brassicaceae), a federally threatened winter annual. Natural Areas Journal 20: 159165.

- Baskin, J. M., \& Baskin, C. C. (2014). What kind of seed dormancy might palms have?. Seed Science Research, 24(01), 17-22. 
- Dirr, M., \&Heuser, C. W. (1987). The reference manual of woody plant propagation: from seed to tissue culture: a practical working guide to the propagation of over 1100 species, varieties and cultivars. Varsity Press. 239.

- Donohue, K., Dorn, L., Griffith, C., Kim, E., Aguilera, A., Polisetty, C. R., \& Schmitt, J. (2005). The evolutionary ecology of seed germination of Arabidopsis thaliana: variable natural selection on germination timing. Evolution, 59(4), 758-770.

- Ellis, R. H., Hong, T. D., \& Roberts, E. H. (1985).Handbook of seed technology for genebanks. v. 2: Compendium of specific germination information and test recommendations. Handbooks for Genebanks (IBPGR). 405.

- Fenner M. and Thompson K. (2005).The ecology of seeds. Cambridge University Press, Cambridge.

- Galme's J., Medrano H. and Flexas J. (2006) Germination capacity and temperature dependence in Mediterranean species of the Balearic Islands. Investigacio'nAgraria: Sistemas y RecursosForestales 15: 88-95.

- Gültekin, H. C., Gulcu, S., Çelik, S., Gurlevik, N., \& Özturk, G. (2007). The effect of stratification periods on germination of services tree (Sorbus L.) seeds. Turkish Journal of Forestry, 2, 42-50.

- Gunes, E., Gubbuk, H., Ayala-Silva, T., Gozlekci, S., \&Ercisli, S. (2013).Effects of various treatments on seed germination and growth of carob (Ceratonia siliqua L.). Pak. J. Bot, 45(4), 11731177.

- Harper J.L. (1977). Population biology of plants. London: Academic Press.

- Hartmann, H. T., Kester, D. E., Davies, F. T. JR. andGeneve, R. L. (1997).Plant Propagation.Principles and practices.Fifth edition.Prentice-Hall International, Inc. 647.

- Imbert E., Youssef S., Carbonell D. and Baumel A. (2012). Do endemic species always have a low competitive ability? A test for two Mediterranean plant species under controlled conditions. Journal of Plant Ecology 5: 305-312.

- Krussmann, G. (1981). The history of the modern garden rose. The Complete Book of Roses, 67105.

- Lawyer, E. M. (1978). Seed germination of stone fruits.In Combined Proceedings International Plant Propagators' Society. (28). 106-109.

- Leck M. A., Parker V. T. and Simpson R. L. (Eds.).(2008). Seedling ecology and evolution.Cambridge University Press.

- Ma'an development center, (2017).Fostering Adaptation to Climate Change among Farming
Systems in the northern Jordan Valley project.Booklet I: Frost tolerant species.

- Mahdi H., Yaseen D., Hussein W., Salih H., Gailan B., Youssef S. (2016). Seed germination ecology of two species of Pistacia from mountain of Kurdistan Region of Iraq (NW Zagrous mountain). Experience carried out in nursery of college of Agriculture, University of Duhok (In revision).

- Masaka, K., \& Yamada, K. (2009). Variation in germination character of Robinia pseudoacacia L.(Leguminosae) seeds at individual tree level. Journal of Forest Research, 14(3), 167177.

- Mattana E., Daws, M. I. and Bacchetta G. (2010).Comparative germination ecology of the endemic Centranthusamazonum (Valerianaceae) and its widespread congener Centranthusruber. Plant Species Biology 25: 165-172.

- McDonald, B. (1986). Practical woodyplant propagation for nursery growers.Timber Press, Portland, Oregon.(1) 660.

- McMillan-Browse, P. D. A. (1978). Stratification - a detail of technique procedure international. Plant Prop. Soc. 28: 191-192.

- Nowak, D. J., Hirabayashi, S., Bodine, A., \& Hoehn, R. (2013). Modeled PM 2.5 removal by trees in ten US cities and associated health effects. Environmental Pollution, 178, 395-402.

- Ortiz P.L., Montserrat A., Talavera S., (1998). Low reproductive success in two subspecies of Juniperus oxycedrusL.. International Journal of Plant Sciences 159: 843-847.

- Peel, M. C., Finlayson, B. L., \& McMahon, T. A. (2007). Updated world map of the KöppenGeiger climate classification. Hydrology and earth system sciences discussions, 4(2), 439473.

- Piotto, B., \& Di Noi, A. (2003). Seed propagation of Mediterranean trees and shrubs. ANPA Handbook. pp. 11-51.

- Pipinis, E., Milios, E., \&Smiris, P. (2011). Effect of sulphuric acid scarification, cold moist stratification and gibberellic acid on germination of Paliurus spina-christi Mill.seeds. Forestry, 17(1), 41.

- Salih, T. W., Nazar, M. S., Gailan, B. A., Hameed, A. R., and Farouq Y., S. (2016). Growth response of Pinus brutia Ten and Melia azedarach L to various growing media under field conditions. Journal of University of Duhok, (19)1: 295-301

- Salim Azad, M., Zedan-Al-Musa, M., \& Abdul Matin, M. (2010).Effects of pre-sowing 
treatments on seed germination of Melia azedarach. Journal of Forestry Research, 21(2), 193-196.

- Skordilis, A., \& Thanos, C. A. (1995). Seed stratification and germination strategy in the Mediterranean pines Pinus brutia and $P$. halepensis. Seed Science Research, 5(03), 151160.

- Takos, I. A. (2001). Seed dormancy in bay laurel (Laurusnobilis L.). New Forests, 21(2), 105-114.

- Takos, I. A., \& Efthimiou, G. S. (2003). Germination results on dormant seeds of fifteen tree species autumn sown in a northern Greek nursery. Silvae Genetica, 52(2), 67-70.

- Takos, I., \& Konstantinidou, E. (2002). Effect of treatments and collection time on seed germination and germination rate of of Albizia julibrissin Durazz seeds. In Proceedings of the 2002 Annual Meeting of IUFRO (Vol. 2, No. 00, pp. 11-15).

- Takos, I., \&Merou, T. (1995).Technology of Woody Plants Seeds. the Technological Education Institute of Kavala. 181.

- Tasoulas, E., Varras, G., Tsirogiannis, I., \& Myriounis, C. (2013). Development of a GIS application for urban forestry management planning. Procedia Technology, 8, 70-80.
- Topham, A. T., Taylor, R. E., Yan, D., Nambara, E., Johnston, I. G., \&Bassel, G. W. (2017). Temperature variability is integrated by a spatially embedded decision-making center to break dormancy in Arabidopsis seeds. Proceedings of the National Academy of Sciences, 201704745.

- Vora, R. S. (1989). Seed germination characteristics of selected native plants of the lower Rio Grande Valley, Texas. Journal of range management, 36-40.

- Young, J. A. and Young, CH. G. (1992).Seeds of woody plants in North America.Dioscorides Press, Portland, Oregon. 407.

- Youssef S. Baumel A. Véla E. Juin M. Dumas E. Affre L. and Tatoni T. (2011). Factors Underlying the Narrow Distribution of the Mediterranean Annual Plant Arenariaprovincialis (Caryophyllaceae). Folia Geobotanica 46: 327-350.

- Youssef, S., Mahmood, A., Mahdi, H., and Vela, E., (2015).New contribution on Orchids (Orchidaceae) of Duhok Province in Kurdistan Region (N-Iraq).Journal EuropäischerOrchideen, 47, pp. 405-420.

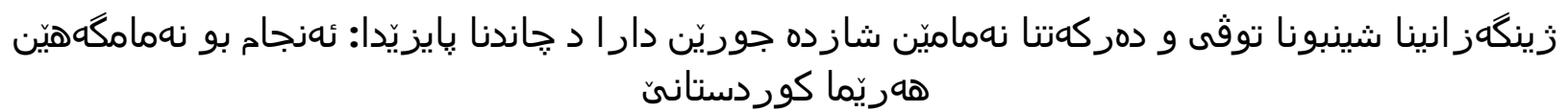

يوخته

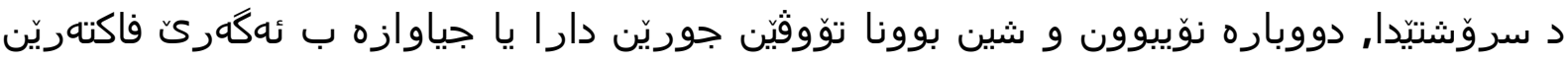

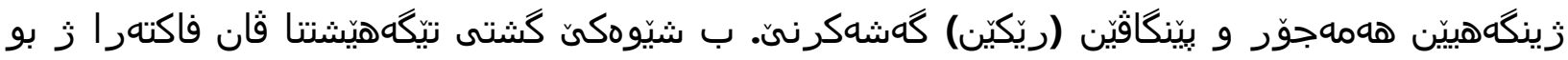

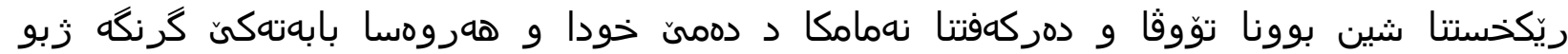

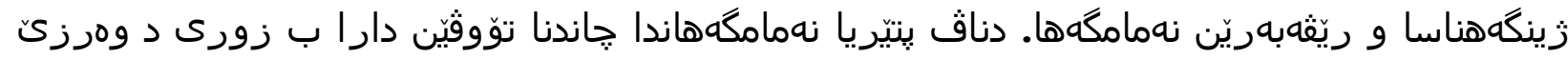

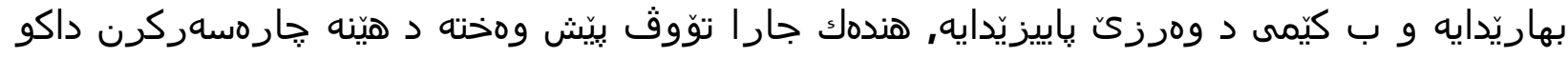

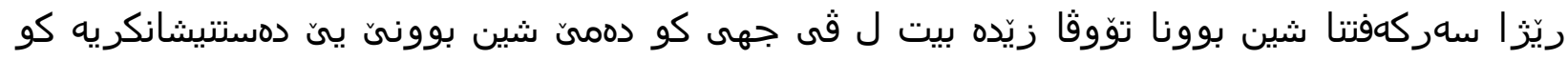

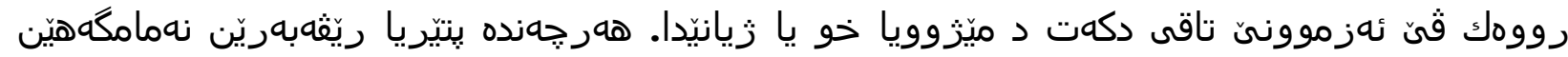

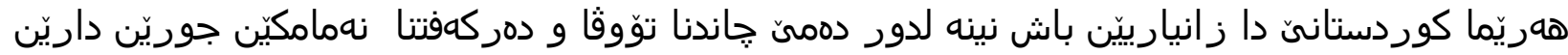

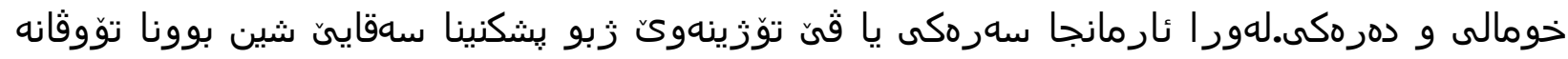

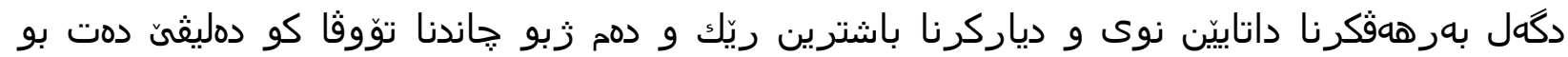

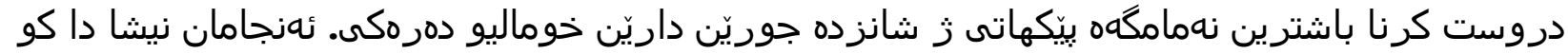

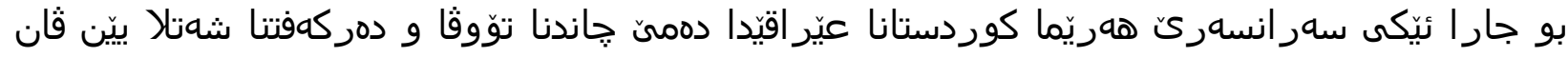

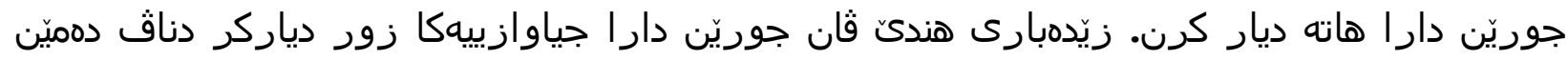

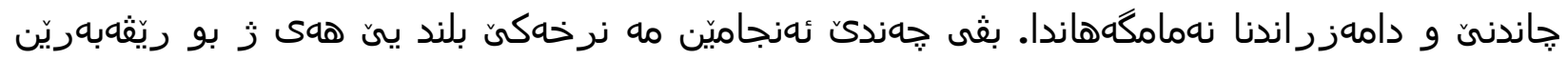




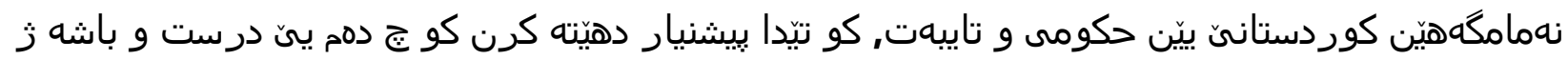

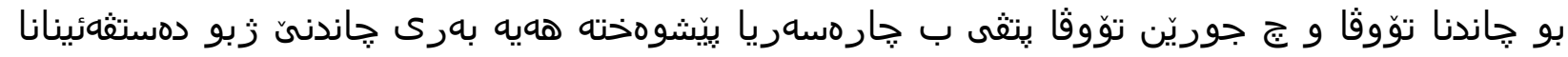
نويبوونهكا باشتر.

بيئة انبات البذور و ظهور الشتلات لستة عشر نوعا من الأشجار المزدوعة في الخريف:

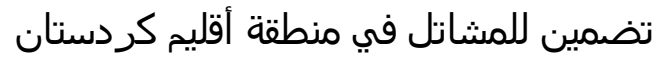

الخلاصة

في الطبيعة، تجديد الانواع وبيئة إنبات بذور انواع الأشجار تختلف فيما لئبة بينها بسبب عملية

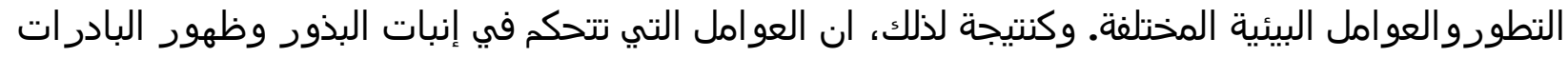

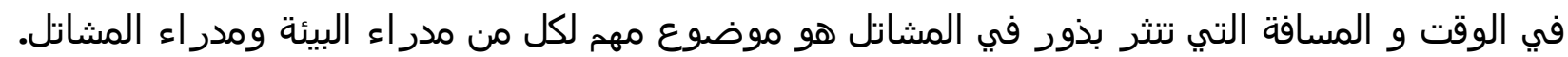

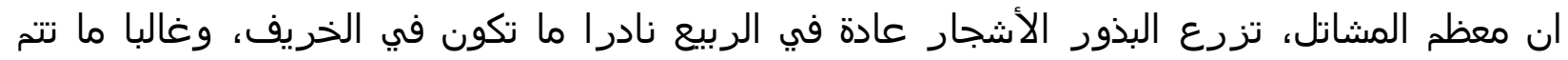

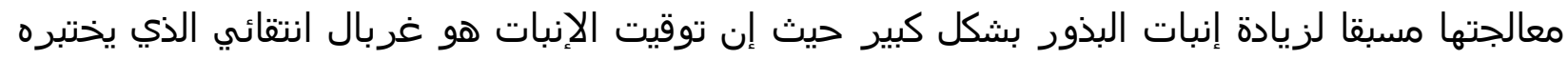

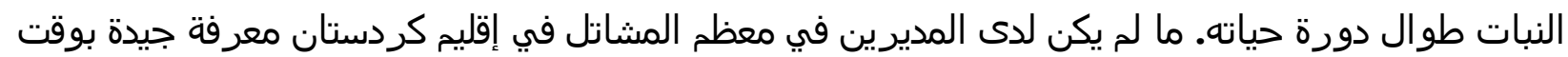

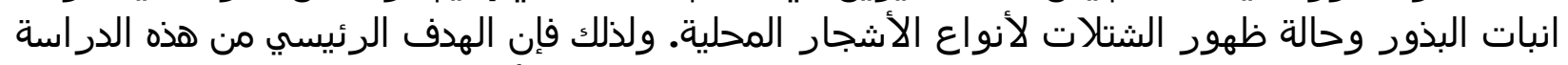

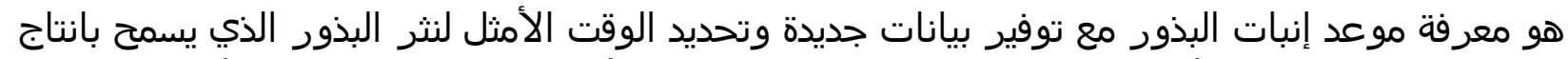

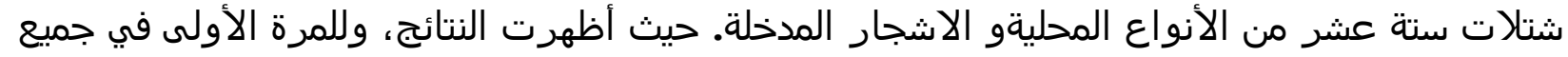

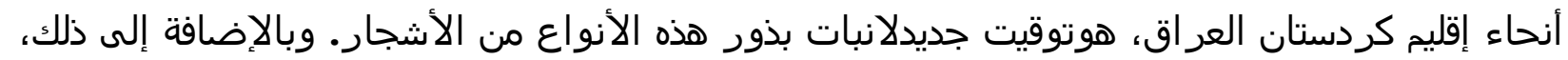

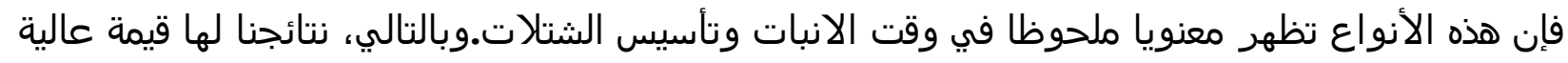

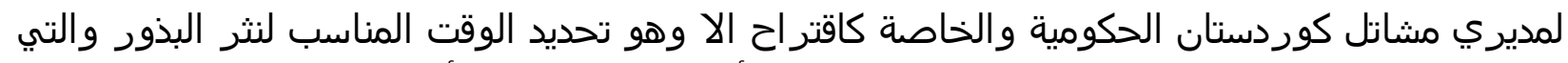

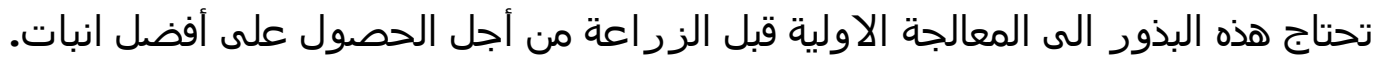

